\title{
The Effect of Glass and Carbon Fibers and Powders Addition on the Sliding Wear Behavior of Unsaturated Polyester Resin
}

\author{
Yahya I. Abdul-Rahman \\ Ismail K. Al-Dahmashy \\ Department of Physics/College of Education/ University of Tikrit \\ Edrees E. Ghadeer \\ Department of Physics/College of Science/ University of Mosul
}

(Received 12/6/2018;Accepted 17/9/2018)

\begin{abstract}
The current investigation is interested in studying the wear phenomenon for unsaturated polyester resin reinforced by a different weight fraction of glass and carbon fibers and powders. The prepared specimens were tested according to standard (ASTM-D5963) using a dvice pin-on-disk, at room temperature. The influence of wear parameter like, applied load, sliding speed on the wear rates were investigated. It was observed that the carbon and two types of glass fibers composite shows lower wear rates than the carbon and glass powders composites, under varying the loads and sliding speeds. In the case of sliding speed increased the results show that the increased of the weight fractions of carbon and glass powders will decrease the wear rates of composites prepared from this powders, while in the case of loading increase the wear rates increased when the weight fraction increased up to $(4.16 \mathrm{Wt} . \%)$ for both carbon and glass powders.
\end{abstract}

Keywords: Sliding Wear, Unsaturated Polyester resin, Pin-On-Disc Tester (Tribometer), Weight Fraction, Glass Fibers, Carbon Fibers.

\section{تأثير إضلفة أليه وسساحق الزجاج والكاربون علعسلوك البل الأنزلفي لرالتنج

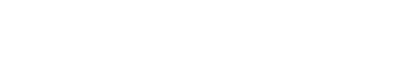

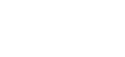

يهمم بحثنا الحالي بدرلسة آلية حدوث ظاهرة البلى لراتنج البولي لأستر غير المشع المقوى بكسور وزنية مختلفة باليف ومسلحق الزجاج والكاربون. لختبرت العينت المحضرة وفة لظلم (ASTM-D5963) بلستخدلم جهاز المسمار على

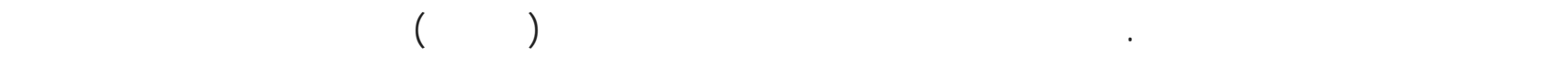

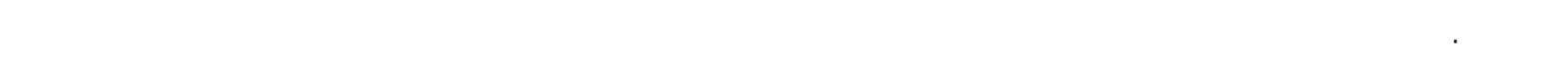

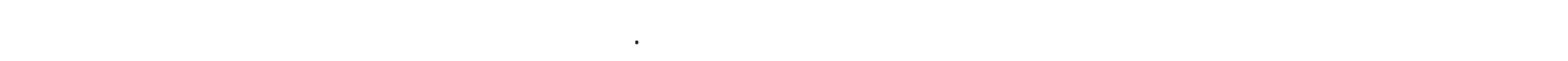

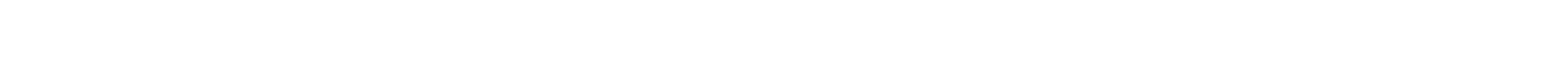
حالة زياة الحمل، فلن معدلات البله ازدادت بزيادة الكسر ألوزني لأعلى من (4.16 Wt.\%) لكل من مسحوق الزجاج والكاربون.

الكاملت الدالة :ألتعرية الأززلاقية، راتنج البولي لأستر، المسماري على القرص، الكسر الوزني، أليف الزجاج، أليف الكاربون. 


\section{INTRODUCTION}

In recent times, there has been a remarkable growth in the large-scale production of fibrous and powders composites materials. As advanced engineering materials, the fibers and powders composites are used in many applications where high wear resistance is required; these include electrical contact brushes, brake disc, cams, clutches, cylinder liners, artificial joints, helicopter blades, many bearing applications and bio-medical applications. The wear properties can be varied substantially through changes in the microstructure, the morphology, volume (or weight) fraction and mechanical properties of the reinforcing phase, and the nature of the interface between matrix and the reinforcement. Most of the machine parts suffer from friction and wear at the interface of the sliding surfaces. Wears are not intrinsic material property but are characteristics of the engineering systems. Wear problems especially abrasive and adhesive type often lead to replacement of components and assemblies in engineering due to changes in dimensions of the mating parts (Halling, 1976).

Many studies have investigated wear rate and attempted to find the effect of volume (or weight) fraction, types and other parameters such as the applied load, sliding velocity, abrasive grit size and sliding time. (Suresha et al., 2006) investigated the tribological properties of the carbon epoxy (C-E) composites and glass epoxy (G-E) composites by using pin-on-disc. The tests are conducted by subject (C-E) and (G-E) samples sliding against a hard steel disc (62 HRC) under different sliding speed and loading conditions. The results illustrated the (C-E) composite show lower fraction and lower slide wear loss compared to (G-E) composite irrespective of the load or speed employed. evaluated the wear characteristic of fiber reinforced dental composite by using glass fiber with different fiber length and different weight fraction added to the dental resin. It was found that the specimen with $(5.7 \mathrm{Wt}$. \%) fiber and fiber length of $(3 \mathrm{~mm})$ performed better wear volume in compared to all other fiber reinforced specimens under all load conditions. (Kumar et al., 2017) studied the wear rate of polymer composite made up of glass fiber reinforced epoxy resin filled with aluminium powder, and reported that the wear rate increased linearly as the load increased by keeping the speed constant and also the wear rate increased as the speed increased by keeping the load constant.

The aim of this study, is to investigate the effect of selected weight fractions $(1.07,2.13,3.16$, $4.19,5.15 \mathrm{Wt} . \%)$ of fibers such as ((E-Glass)chopped strand laminates fibers, (E-Glass)Net laminates fibers, Glass powder, Carbon continuous fiber, and Carbon powder) on the wear rate characteristics of unsaturated polyester resin under dry sliding conditions, such as applied load, sliding speed at room temperature.

\section{Materials}

\section{Experimental}

The matrix used in this study was unsaturated polyester resin, manufactured by a company of SIR Saudi Arabia, It is Viscous Liquid, transparent, pink, good mechanical properties, bonding with other materials, thermal and electrical insulation, good surface after Setting, dimension stability and it is type of thermosetting polymer, (Table 1) gives some properties of unsaturated polyester resin (Chungm, 2010):

Table 1: mechanical Properties of unsaturated polyester resin

\begin{tabular}{|c|c|c|c|c|c|c|c|}
\hline Name & $\begin{array}{c}\text { Density } \\
\left.\mathbf{( g m}^{\mathbf{3}} \mathbf{c m}^{\mathbf{3}}\right)\end{array}$ & $\begin{array}{c}\text { Fracture } \\
\text { Toughness } \\
\text { (MPA.M }^{\mathbf{0 . 5}} \text { ) }\end{array}$ & $\begin{array}{c}\text { Tensile } \\
\text { Strength } \\
\text { (MPA) }\end{array}$ & $\begin{array}{c}\text { Percent } \\
\text { Elongation } \\
\text { (EL\%) }\end{array}$ & $\begin{array}{c}\text { Modulus of } \\
\text { Elasticity } \\
\text { (GPA) }\end{array}$ & $\begin{array}{c}\text { Compression } \\
\text { Strength } \\
\text { (MPA) }\end{array}$ & $\begin{array}{c}\text { Bending } \\
\text { Strength } \\
\text { (MPA) }\end{array}$ \\
\hline $\begin{array}{c}\text { Polyester } \\
\text { resin }\end{array}$ & 1.2 & 0.6 & $89.7-41.4$ & $<2.6$ & $2.06-4.11$ & 100 & 125 \\
\hline
\end{tabular}


The liquid resin converts to solid by mixing (2\%) of Methyl Ethyl Ketone Peroxides (MEKP) as a hardener with $(0.4 \%)$ Cobalt actuate as accelerator to solidification. This mixing is done for each $(100 \%)$ of un saturated polyester resin at room temperature.

\section{Glass Fiber}

In this research, the reinforcement materials type (E-Glass) used as laminates chopped strand mat and net laminates fibers, wear about of $(4 \mu \mathrm{m})$ and $(1 \mathrm{~mm})$ diameter, respectively, have been used for strengthening the matrix (Unsaturated polyester), Table(2) gives the composition of the (E- glass) fibers (Wake, 1977):

Table 2: composition of (E- glass) fibers

\begin{tabular}{|c|c|c|c|c|c|c|c|c|c|}
\hline Material & $\mathbf{S i O}_{\mathbf{2}}$ & $\mathbf{C a O}$ & $\mathbf{A l}_{\mathbf{2}} \mathbf{O}_{\mathbf{3}}$ & $\mathbf{M g O}$ & $\mathbf{B}_{\mathbf{2}} \mathbf{O}_{\mathbf{3}}$ & $\mathbf{T i O}_{\mathbf{2}}$ & $\mathbf{N a}_{\mathbf{2}} \mathbf{O}$ & $\mathbf{F e}_{\mathbf{2}} \mathbf{O}_{\mathbf{3}}$ & $\mathbf{F}$ \\
\hline Weight Percent (wt\%) & 53 & 22 & 13 & 3 & 6 & 0.5 & 1.6 & 0.8 & 0.1 \\
\hline
\end{tabular}

The two types of fibers which used in this research was shown in figure (1). The physical and mechanical properties of (E-Glass) fiber is given in (Table 3) (William and Javad, 2006).

Table 3: some properties of (E-Glass) fibers

\begin{tabular}{|c|c|c|c|c|c|}
\hline $\begin{array}{c}\text { Water Absorption } \\
(\%)\end{array}$ & $\begin{array}{c}\text { Thermal } \\
\text { Coductivity } \\
\left(\mathbf{W} / \mathbf{m}^{\mathbf{0}}\right)\end{array}$ & $\begin{array}{c}\text { Cofficient of } \\
\text { thermal } \\
\text { Expansion } \\
\left(\mathbf{1 0}^{-\mathbf{6}} \mathbf{k}^{-\mathbf{1}}\right)\end{array}$ & $\begin{array}{c}\text { Modulus of } \\
\text { elasticity }\end{array}$ & $\begin{array}{c}\text { Elongation } \\
\text { at Break } \\
\text { (\%) }\end{array}$ & $\begin{array}{c}\text { Density } \\
\left(\mathbf{K g} / \mathbf{m}^{\mathbf{3}}\right)\end{array}$ \\
\hline $0.1<$ & 1 & 5 & 73 & 2.9 & 2600 \\
\hline
\end{tabular}

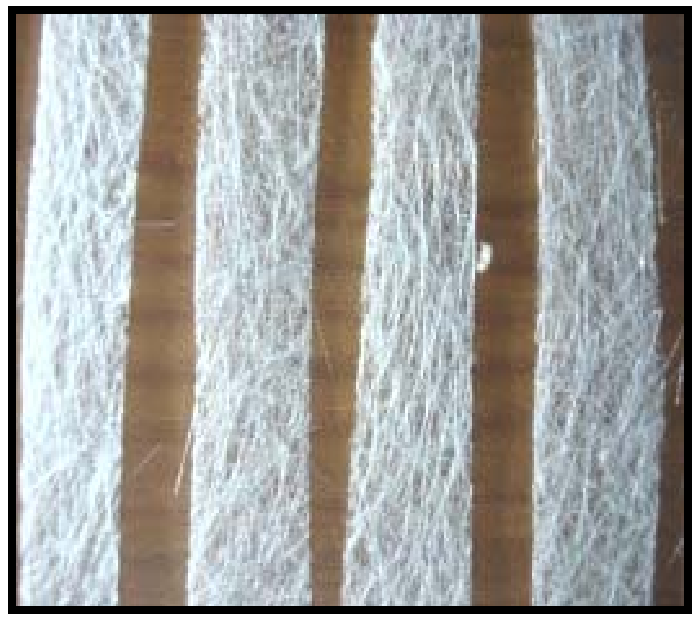

(B)

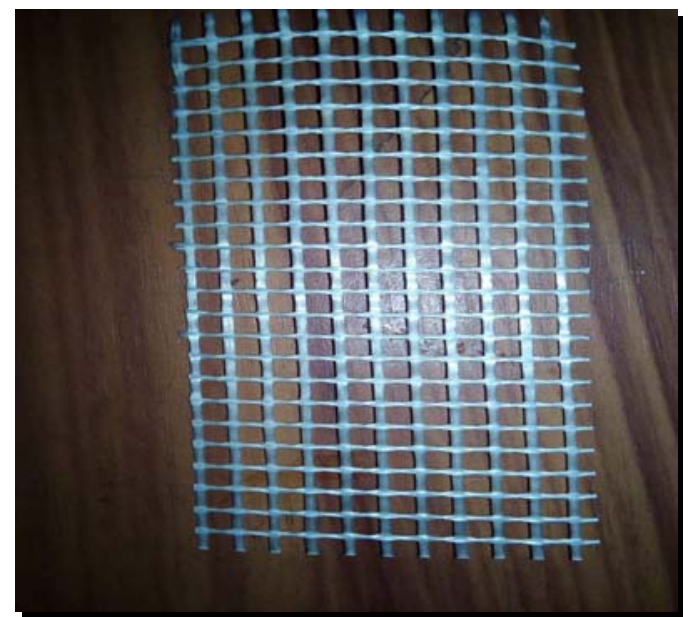

(A)

Fig. 1 : (A) (E-Glass) Net laminate fiber, (B) (E-Glass)chopped strand laminates fibers

These fibers(strand or net) was immersed in the form of regular manner into the resin.

\section{Glass powder}


Glass powder, as shown in Fig. (2), is generally the inert materials which are used in composite materials to reduce material costs, improve mechanical properties to some extent, toughness, high heat resistance, high sound and electric insulation, great chemical resistance and in some cases to improve process ability (Al-Nueimi, 2013).

Glass powder of particle size $(2-4 \mu \mathrm{m})$ added in the final of mixing a resin, gradually and slowly with the hardener and accelerator in a beaker at room temperature. Glass Powders surpass many characteristics which is given in (Table 4) (William and Javad, 2006).

Table 4: some properties of Powder glass

\begin{tabular}{|c|c|c|c|c|}
\hline $\begin{array}{c}\text { Water Absorption } \\
\text { (\%) }\end{array}$ & $\begin{array}{c}\text { Thermal } \\
\text { Coductivity } \\
\left(\mathbf{W} / \mathbf{m}^{\mathbf{0}} \mathbf{)}\right.\end{array}$ & $\begin{array}{c}\text { Cofficient of Thermal } \\
\text { expansion } \mathbf{( \mathbf { 1 0 } ^ { - 6 } / \mathbf { k } ^ { - 1 } )}\end{array}$ & $\begin{array}{c}\text { Tensile } \\
\text { Strength(Mpa) }\end{array}$ & $\begin{array}{c}\text { Density } \\
\left(\mathbf{K g} / \mathbf{m}^{\mathbf{3}}\right)\end{array}$ \\
\hline $0.5<$ & 1.1 & 7 & 54 & 2400 \\
\hline
\end{tabular}

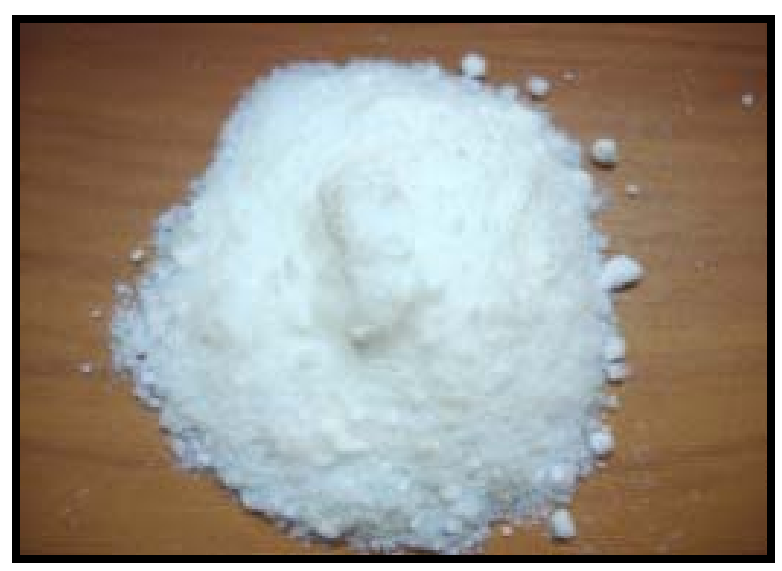

\section{Carbon Fiber}

Fig. 2: Glass Powder

Carbon Fiber, as shown in Fig. (3), reinforced is extensively used in numerous industrial applications because of some outstanding physical, thermal and mechanical properties which are realizable with the combination of fiber and matrix resin, particularly lightweight, high stiffness and strength, good fatigue resistance, excellent corrosion resistance and dimensional stability compared with metallic materials, carbon fiber about $(8 \mu \mathrm{m})$ in diameter, carbon fiber surpass many characteristics which is given in (Table 5).

Table 5: some properties of carbon fiber

\begin{tabular}{|c|c|c|c|c|c|}
\hline $\begin{array}{c}\text { Friction } \\
\text { coefficient(M) }\end{array}$ & $\begin{array}{c}\text { rmalThe } \\
\text { Coductivity } \\
\left(\mathbf{W} / \mathbf{m}_{\mathbf{k}} \mathbf{\mathbf { 0 }}\right)\end{array}$ & $\begin{array}{c}\text { Elongation at } \\
\text { Break } \\
\mathbf{( \% )}\end{array}$ & $\begin{array}{c}\text { Coeff. of } \\
\text { thermal exp. }\end{array}$ & $\begin{array}{c}\text { Specific Heat } \\
\left(\mathbf{J} / \mathbf{K g} . \mathbf{k}^{\circ}\right)\end{array}$ & $\begin{array}{c}\text { Density } \\
\left(\mathbf{K g} / \mathbf{m}^{3}\right)\end{array}$ \\
\hline $0.3-0.4$ & 2 & 1.3 & 2 & 495 & 1800 \\
\hline
\end{tabular}




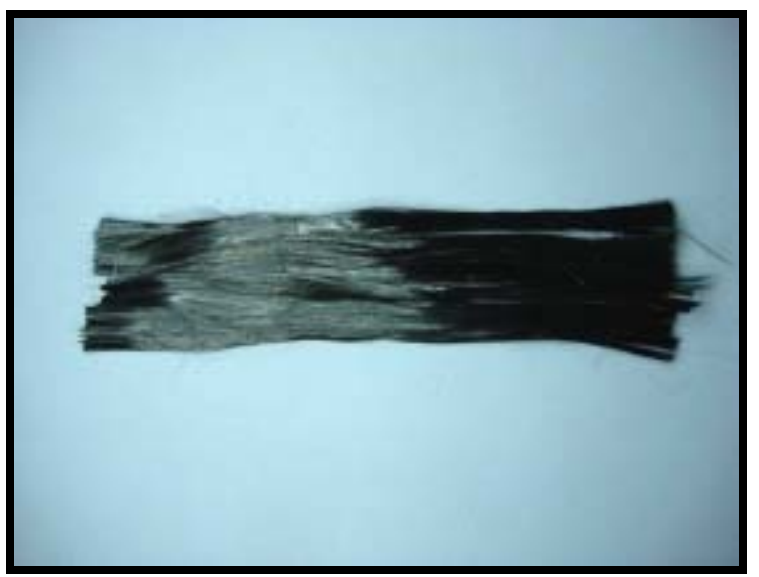

Fig. 3: Carbon fiber

\section{Carbon Powder}

Carbon powder, as shown in Fig. (4), is most often added to polymers to improve tensile and compressive strength, abrasion resistance, toughness, dimensional and thermal stability, and other properties. because these inexpensive material replace some volume of the more expensive polymer, the cost of the final product is reduced

Glass powder of particle size $(10-100 \mu \mathrm{m})$ added in the final of mixing a resin, gradually and slowly with the hardener and accelerator in a beaker at room temperature. Carbon powders surpass many characteristics which is given in (Table 6)

Table 6: some properties of carbon powder

\begin{tabular}{|c|c|c|c|c|}
\hline $\begin{array}{c}\text { Vickers } \\
\text { Hardness }\end{array}$ & $\begin{array}{c}\text { Water rptionAbso } \\
\mathbf{( \% )}\end{array}$ & Ther. Cond. & $\begin{array}{c}\text { Tensile } \\
\text { Strength(MPa) }\end{array}$ & $\begin{array}{c}\text { Density } \\
\left(\mathbf{K g} / \mathbf{m}^{\mathbf{3}}\right)\end{array}$ \\
\hline $90>$ & 10 & 45 & 50 & 2400 \\
\hline
\end{tabular}

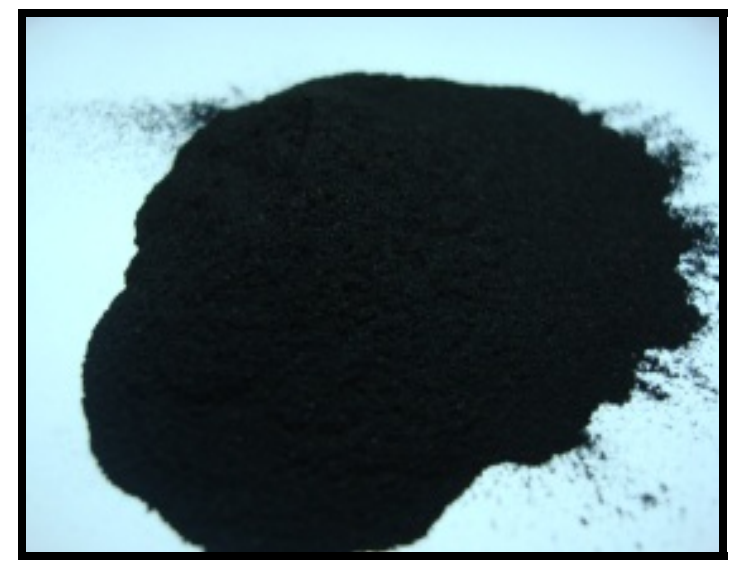

Fig. 4: carbon powder 


\section{Composites Preparation}

1- Hand-lay-up and open mould techniques was used in a laboratory to prepare the (E-Glass)chopped strand laminates fibers, (E-Glass) Net fiber, glass powder, carbon fiber, and carbon powder reinforced polyester composite.

2- The glass mould used was cut and cleaned, with dimensions $(20 \times 10 \times 10 \mathrm{~cm})$ for the sliding wear tests according to ASTMD-5963.

3- The mould has initially been polished with release agent to prevent the composites from sticking on the mould upon removal.

4- The weight percent of the fibers or powders in the composite was ranging $(1.07-5.15)$, which was calculated by Eq.(1) :

$$
\mathrm{Wt} \% \text { of the fibersin the composite }=\frac{\text { Weightof fibers }}{\text { Weightof polyester }+ \text { weightof fibers }} \times 100 \% \ldots \text { (1) }
$$

5- The two types of glass fibers and carbon fiber were impregnated with resin by pouring the resin on the fibers from one corner to the mould after putting fibers into the mould to avoid the bubble formation which causes cast damage and the uniform pouring was continued until the mould was filled to the required level. Care was taken as we can to evenly distribute the fibers in the mould to ensure a uniform sample and to prevent the clump and tangle the fibers together during pouring the resin.

6- The (glass) and (carbon) powders and the matrix (including the accelerator and the hardener) were mixed at room temperature continuously and slowly to avoid bubbling during mixing .The process was continued for (5) minutes until the mixture became homogeneous, then The mixture was poured from one corner into the mould to avoid the bubble formation which causes cast damage and the uniform pouring was continued until the mould was filled to the required level.

7- Samples was then pressed in a $0.3 \mathrm{MPa}$ left in the mould for (24) hrs at room temperature to solidify, then, taken out of the mould and leave in the air for another (24) hrs, then heat treatment in oven in $\left(55 \mathrm{C}^{0}\right)$ at $(1 \mathrm{hr}$.) to complete polymerization .whole assembly then released and allowed to cure for a 7 days at room temperature.

\section{Tribometer (Pin-on-disc type)}

\section{TRIBOLOGICAL TEST}

The test set-up used to perform this experiment is pin-on-disc type set up as shown in Fig. (5), which used to measure the wear rates of the prepared samples. The samples are of rectangular cross sections of size $(20 \times 10 \times 10 \mathrm{~mm})$ according to ASTM-D 5963 their initial weight is recorded using the electronic balance of accuracy $0.0001 \mathrm{mg}$ after cleaning. The rotating disc used is made of aluminum with friction surface of (400\#). the tests are carried out on the selected parameters by varying the load $(16,20,24,28,32)$ or velocity $(60,90,120,150)$ for all samples. The surface of samples and the disc are cleaned using acetone before performing the test. After fixing the sample inside the sample holder, the normal load through a pivoted loading lever or different velocities to the rectangular sample was applied. As the test time is finished, the rotating disc was stopped. the weight of the sample is measured and then cleaned with acetone to remove the debris which adheres to the specimens and weight again. The difference in the initial weight and final weight gives the rate of wear of the samples at different loading conditions. 


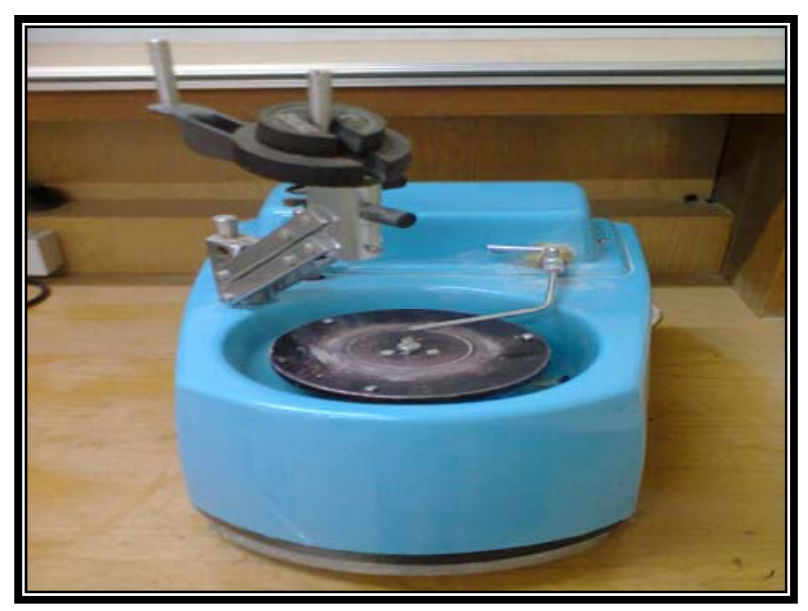

Fig. 5 : pin-on-disc Aperture

The wear rate is calculated using the following relations (Eyre, T.S.1996):

$$
\begin{aligned}
& \mathrm{W} . \mathrm{R}=\Delta \mathrm{W} / \mathrm{S}_{\mathrm{D}} \\
& \Delta \mathrm{W}=\mathrm{W}_{1}-\mathrm{W}_{2} \\
& \mathrm{~S}_{\mathrm{D}}=2 \pi \mathrm{Nr} \mathrm{t}
\end{aligned}
$$

Where:

$\Delta \mathrm{W}$ : Is the weight loss of the specimen before and after the wear test (gm).

$\mathrm{S}_{\mathrm{D}}$ : Is the sliding distance $(\mathrm{cm})$.

$\mathrm{N}$ : Is the no. of revolutions of the rotating disc (rev. $/ \mathrm{min}$ ).

$\mathrm{t}$ : Is the sliding time (min).

The sliding velocity is evaluated from the following relationship[7] :

$$
\mathrm{V}_{\mathrm{S}}=\pi \mathrm{DN} / 60
$$

Where:

$\mathrm{D}$ : Is the circular sliding diameter $(\mathrm{cm})$.

\section{RESULTS AND DISCUSSION}

The variation of wear rate with the applied normal load of unsaturated polyester before and after reinforced with the different percent of ( Wt.\%) at working condition (speed $=0.25 \mathrm{~m} / \mathrm{sec}$. and sliding time $=300 \mathrm{sec}$ ) for reinforcing fibers and powders, has been shown in Fig. (6). 


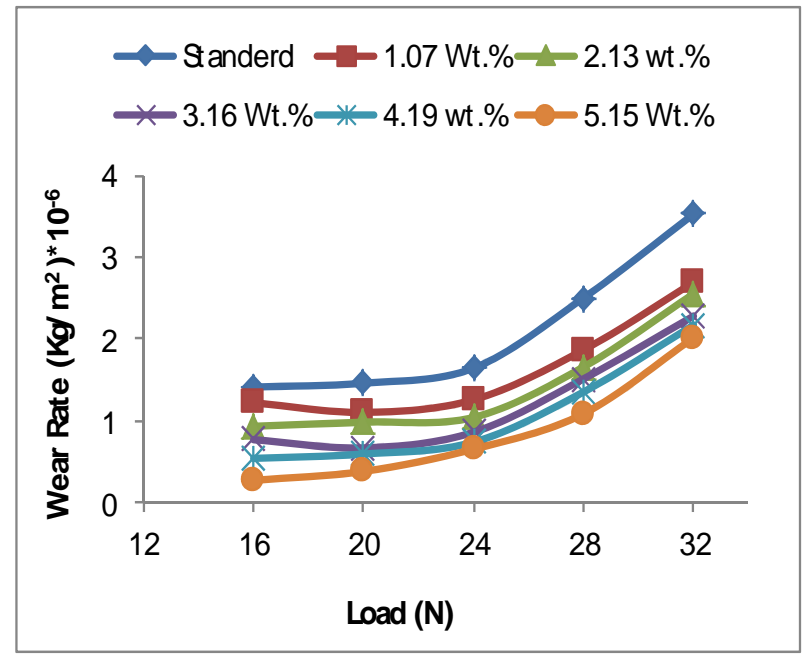

(A)

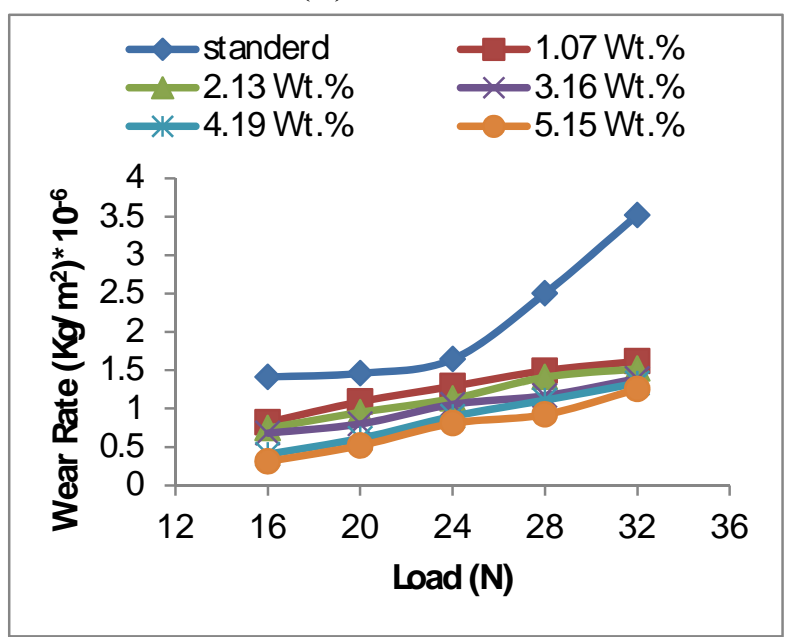

(C)

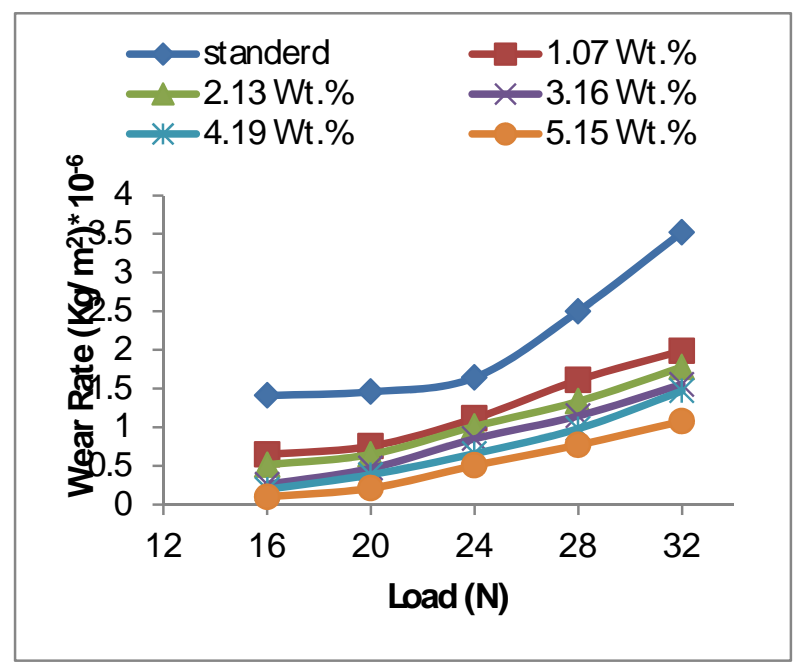

(B)

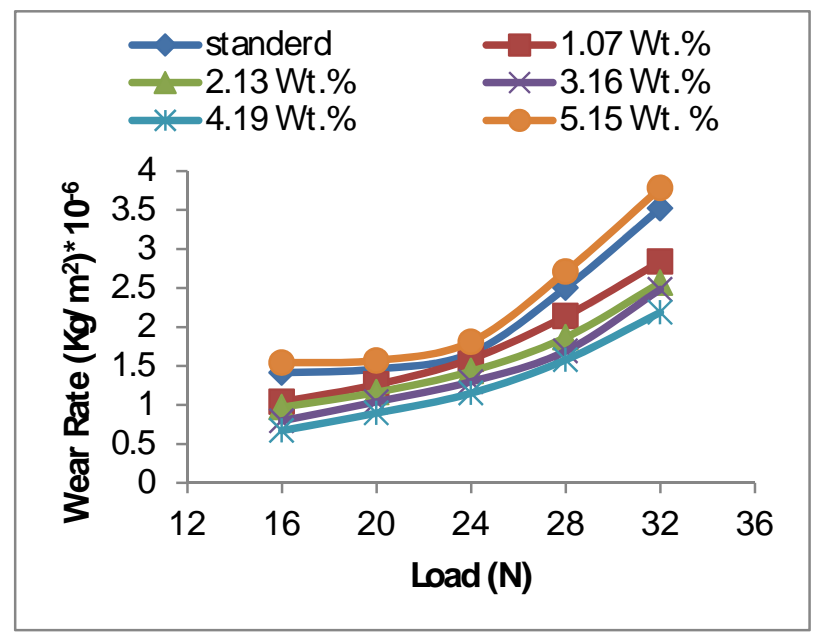

(D)

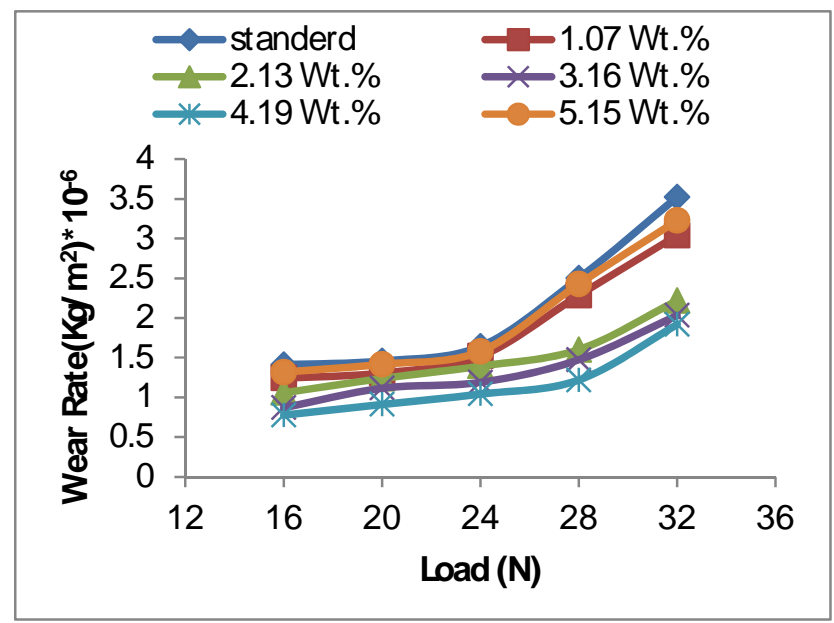

(E)

Fig. 6 : Relationship Between the Wear Rate and Normal Load of the Unsaturated Polyester Reinforced by: (A) (E-glass) chopped strand laminates fibers, (B) (E-glass)Net laminates fibers, (C) Carbon continuous fiber, (D) glass powder, (E) carbon powder 
In general, It can be seen that as the applied load increases, the wear rate of the reinforced and unreinforced samples increases for all types of composite. As well as, as the percentage of reinforcement materials increases, the wear rate of the composite decreases for both reinforcing fibers and powders, This improvement of wear resistance is due to presence of reinforcing fibers and powders that lead to increase the average hardness of the composite which consequently decreases the wear rate of the prepared composite.

The (E-glass) net laminates fiber, shows aminimum wear rate in comparision with the other types of reinforcement, because this type of fibers have good hardness properties, as well as, orientation of this fibers with a net figure $\left(\theta=90^{\circ}\right)$, give the composite which made from this fibers hardenability .In other word the strong atomic binding between matrix and fibers will decrease plastic deformation which come from increasing load during wear test. This result is corresponding with the study (Johns et al., 1989), which was indicated that when the material is in the elastic deformation range, the bond breakage and subsequent crack propagation does not occur and thus the wear loss is very small.

It was also observed from Fig. (6) that, other types of composites fibers. Show adecreasing in the wear rate with increasing the weight fraction of reinforcement materials. Except the reinforcement by carbon and glass powders which show increases in the wear rate with the increases of the weight fraction of (4.19 Wt.\%), as show in Fig. (6 D, E).

Fig. (7), illustrate the effect of the weight fraction of the composite materials on the wear rate. Load was constant at $(16 \mathrm{~N})$.

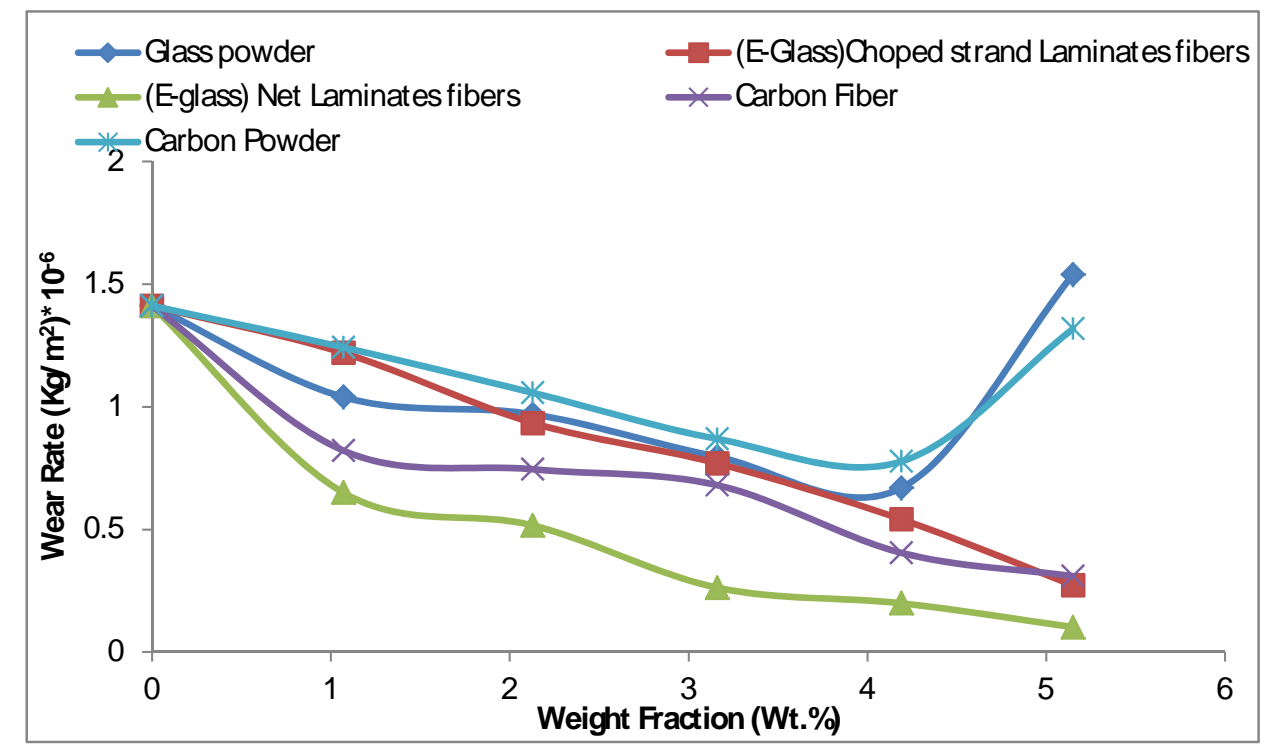

\section{Fig. 7: Relationship Between the Weight Fraction and the Wear Rate of Unsaturated Polyester Reinforced by glass and carbon fibers and powders at load vary}

It is clearly seen that, the increases the weight fraction of carbon and glass fibers lead to decreas the wear rate, which approach to $\left(0.1021 * 10^{-6} \mathrm{Kg} / \mathrm{m}^{2}\right)$ and $\left(0.3101 * 10^{-6} \mathrm{Kg} / \mathrm{m}^{2}\right)$ for both (E-glass) net laminates fibers and carbon continuous fibers, respectively, at the weight fraction at $(5.15 \mathrm{Wt} . \%)$, which consider as the optimum concentration of these fibers in this composites.

On the other hand, the optimum concentration of glass and carbon powders composites is (4.19 Wt.\%) corresponding the wear rate of $\left(0.67 * 10^{-6} \mathrm{Kg} / \mathrm{m}^{2}\right)$ and $\left(0.7775^{*} 10^{-6} \mathrm{Kg} / \mathrm{m}^{2}\right)$, respectively. 
Fig. (8), shows the variation of wear rate with the sliding speed of the unsaturated polyester Unreinforced and reinforced by different weight fraction of $(1.07,2.13,3.16,4.19,5.15 \mathrm{Wt} . \%)$ glass and carbon fibers and powders, at working condition of (load $=16 \mathrm{~N}$, sliding time $=300 \mathrm{sec}$.).

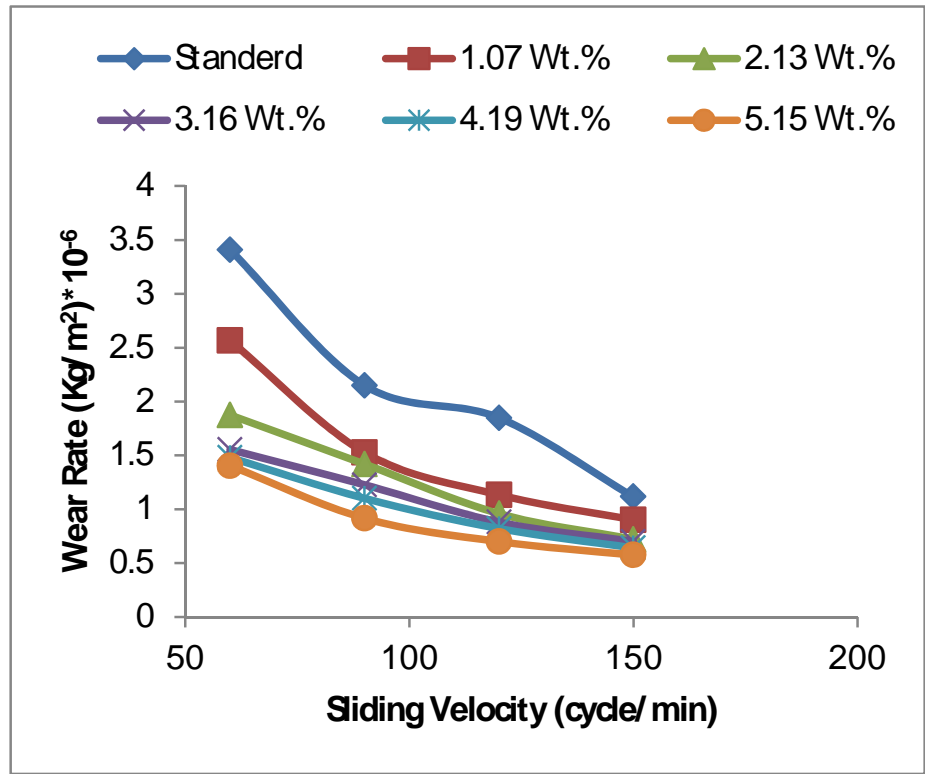

(A)

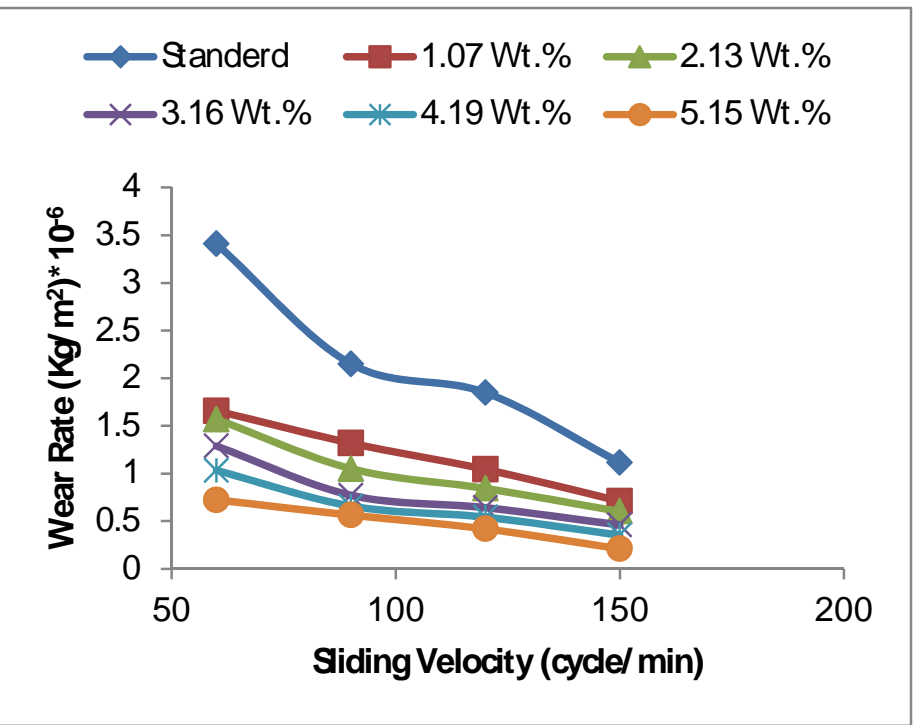

(C)

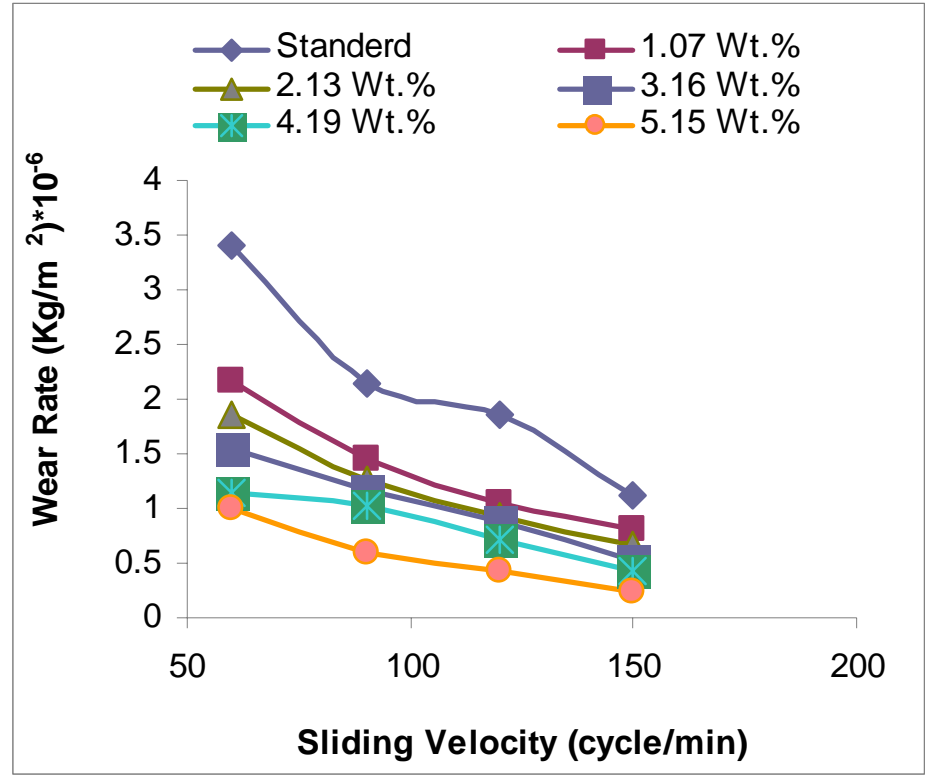

(B)

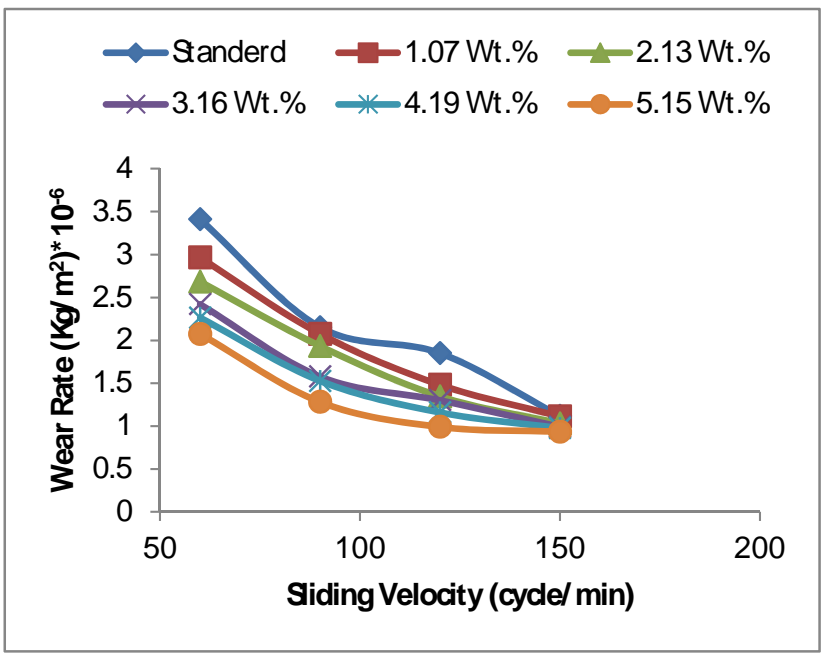

(D) 


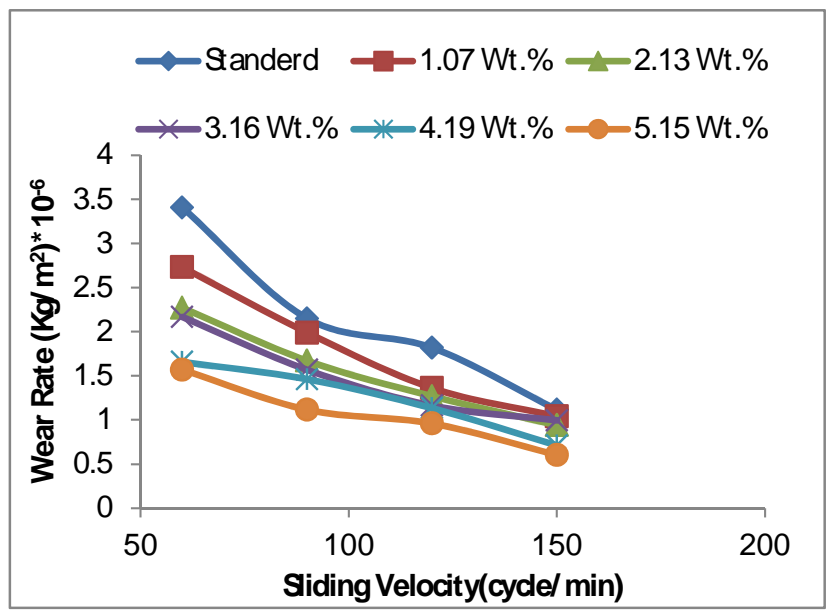

(E)

Fig. 8 : Relationship Between the Wear Rate and Sliding Speed of Unsaturated Polyester Reinforced by glass and carbon fibers and powders

The data show that the weight loss decreases with increases sliding velocity for all types reinforced composite.

It was also observed that the wear rates are high at the sliding velocity of $(60 \mathrm{cycle} / \mathrm{sec})$ then decreases to its lowest value at $(150 \mathrm{cycle} / \mathrm{sec})$, this is due to reduce in contact time between composite specimen and counter face of Pin-on-disc tribometer. This is similar to references (Damarla and Tech, 2005).

Fig. (9) shows the variation in of wear rate versus different of weight fraction of reinforcement of glass and carbon fibers and powders, as sliding velocity is kept constant (60 cycle/min).

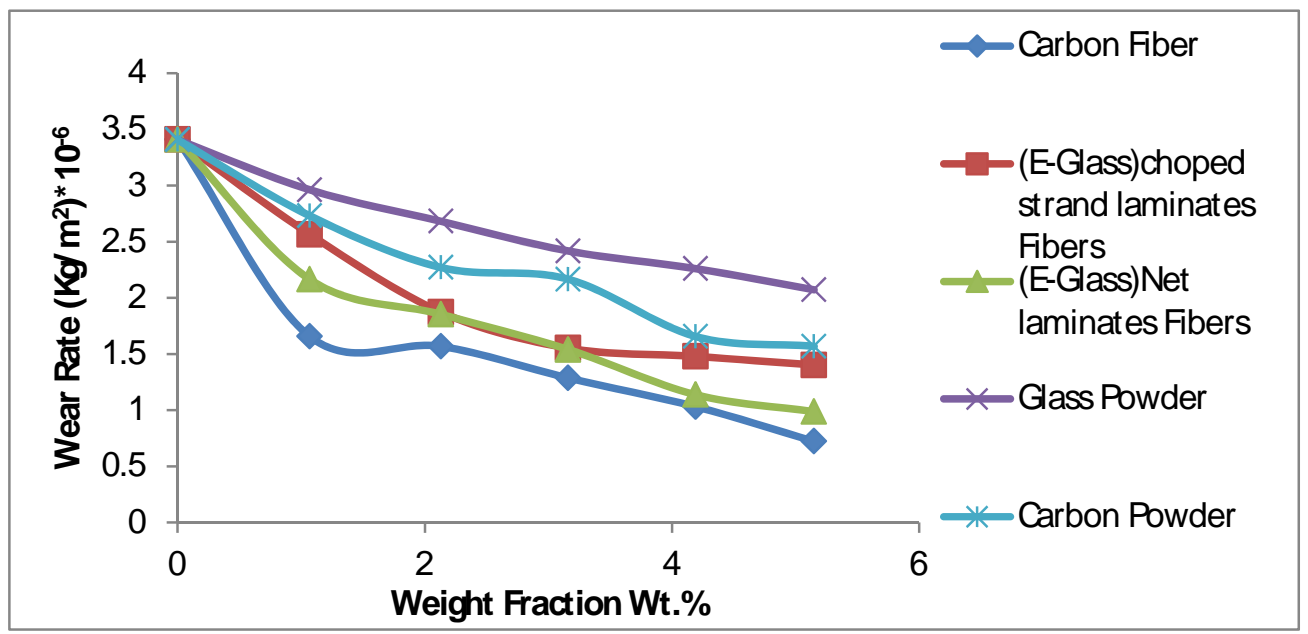

Fig. 9: Relationship Between the Weight Fraction and the Wear Rate of Unsaturated Polyester Reinforced by glass and carbon fibers and powder at varying sliding velocity

It is clear from this figure that, the wear rates of the composites pin decreases in non linear relationship with the increase of weight fraction of reinforcement materials of this composites, this behavior has been observed by a number of researchers (Suresha, 2006). 
More over, The wear rate of the unreinforced polyester is more than that of the other reinforced composites, such as, carbon fibers composites which show an excellent decreasing behavior in the wear rate which reach to $(24 \%)$ in comparison with un saturated polyester which consider as the optimum concentration of this fiber and all reinforcing composite.

The decreasing behavior in the wear rate of this composite is due increasing reinforcing materials concentration, and these will reducing plastic deformation due to the rising sliding velocity.

\section{CONCLUSION}

The experimental work done on the effect of fibers and fillers loading on the tribological behavior of unsaturated polyester resin, Leads to obtained the following conclusions from the present study as follows :

1. The wear rate results of all glass and carbon fibers and powders reinforced polymer composites were better that those without reinforced.

2. The wear rates of all composites testing materials increases with increase of the applied load, while the wear rates of all composites decreases with increase of the applied sliding velocity.

3. Under the load changing, The wear test shows that the (E-glass) net laminates fiber composite with the weight friction of $(5.15 \mathrm{Wt} . \%)$ is a better choice for frictional application a sit has exhibited lowest wear rate of $\left(0.1021 * 10^{-6} \mathrm{Kg} / \mathrm{m}^{2}\right)$ in comparison with other types of composites, when the sliding velocity changes the composites of carbon fiber with the weight fraction of (5.15Wt.\%) exhibited lowest wear rate of $\left(0.7236^{*} 10^{-6} \mathrm{Kg} / \mathrm{m}^{2}\right)$ in comparison of other types of composite.

\section{REFERENCES}

Al-Nueimi, M.A.; Al-Obeidi, E.E. (2013). The effect of (E-glass) fibers and powder addition on the alternating fatigue behavior of unsaturated polyester resin. J. Al-Rafidian Sci.,24(6), 96115.

Chungm, D.D.L. (2010). "Composite Material Science and Application". $2^{\text {nd }}$ ed., Spring Verlag, London, $481 \mathrm{p}$.

Damarla, G.; Tech, B. (2004). Determination of wear in polyester using multiple scratch test. M. Sc. Thesis, University of North Texas.

Eyre, T.S. (1996). Wear characteristic of metal. Triobology, Iteruational.

Halling, J. (1976). "Introduction to Tribology". Wykeman, London.

Johns, G.; Storer, R.A.; Loux, L.A. (1989). "Annual book of ASTM standard". Section, Plastics (I), (08.01), Easton, M.V.S.A.

Kumar, S.; Shivashankar, G.S.; Dhotey, K.; Singh, J. (2017). Experimental study wear rate of glass fiber reinforced epoxy polymer composites filled with Aluminum powder. Advanced Materials, Manufacturing, Management and Thermal Sci.

Pradhan, A.; Jena, H. (2016). Study of solid particle erosion wear behavior of bamboo fiber reinforced polymer composite with cenosphere filler. Advances in Polymer Technology, 37(3).

Suresha, B.; Chandramohan, G.; Samapthkumaran, P.; Seetharamu, S.; Vynatheya, S. (2006). Friction and wear characteristic of carbon-epoxy and glass-epoxy woven roving fibers composites. J. Reinforced Plastics and Composites, 25(7).

Wake, W.C. (1977). "Development in adhesive". Applied Science Pub., London, 499 p.

William, F.S.; Javad, H. (2006). "Foundations of Materials Science and Engineering". $4^{\text {th }}$ ed. Mc Grew Hill higher education. 653 p. 